\title{
Dukungan Keluarga Dengan Tingkat Depresi Pasien Gagal Ginjal Kronis Yang Menjalani Hemodialisa \\ (Studi Korelasi Di Rumah Sakit Gatoel Mojokerto)
}

\author{
Darsini, S. Kep., Ns., M. Kes
}

\begin{abstract}
Depression is a psychological effect that is common in patients with chronic health problems such as ESRD (End Stage Renal Disease). Depression is often associated with increased morbidity of the disease. The results of preliminary studies that the researchers did found that $85 \%$ of patients with chronic renal failure undergoing regular hemodialysis at Gatoel Hospital Mojokerto depressed. Strong support system can speed up recovery of depressive episodes. The purpose of this study to determine the relationship of family support with levels of depression chronic renal failure patients undergoing hemodialysis. The research is to the type of research corellation. The population in this study were patients with chronic renal failure undergoing hemodialysis at Gatoel Hospital Mojokerto by the number of samples taken by 30 respondents with technique thst is consecutive sampling. The results showed that the majority (90\%) patients with chronic renal failure undergoing hemodialysis were depressed with the largest proportion is mild and moderate depression (40\%). Judging from the absence of family support is known that most of the $53 \%$ get enaugh family support. Spearman Rank Test results of the analysis results obtained $p=0,020<\alpha=$ 0,05 , so $\mathrm{Ha}$ is received it means there is a relationships of family support with levels of depression chronic renal failure patients undergoing hemodialysis at Gatoel Hospital Mojokerto. Family support is an important form of support system for patients who are depressed. Family support appropriate and as required improved the lives an improve quality of live. Families can always be expected to provide support so that patients can develop coping mechanism and problem solving are effective.
\end{abstract}

\section{Keywords : Family Support, Depression, GGK, Hemodialysis}

\section{Pendahuluan}

Gagal ginjal kronis merupakan suatu kondisi penurunan progresif fungsi ginjal selama periode bulan atau tahun. Tahap akhir dari gagal ginjal kronik sering disebut dengan End Stage Renal Disease (ESRD) (Anonim, 2011). Dalam penyakit ginjal stadium akhir ini, ginjal kehilangan fungsinya secara irreversibel untuk mempertahankan metabolisme dan homeostasis tubuh (Smeltzer \& Bare, 2002). Menurut Sinaga (2007) dalam Anonim (2008) apabila pasien telah mengalami GGK (Gagal Ginjal Kronik) stadium berat, untuk mempertahankan hidupnya diperlukan terapi sementara berupa cuci darah (hemodialisa). Masalah psikologis yang umum terjadi pada pasien dengan ESRD yang menjalani hemodialisa adalah depresi (Fredric \& Susan, 2010). Secara khusus, depresi dapat mempengaruhi fungsi imunologi, nutrisi, dan faktor-faktor yang mempengaruhi terapi dan kepatuhan dialisis. Konsekuensi dari depresi pada pasien dialisis dapat memperkuat dampak dari penyakit kronis, dan meningkatkan kecacatan fungsional dan penggunaan pelayanan kesehatan. Selain itu keadaan depresi ini mengurangi kualitas hidup dan memiliki dampak klinis negatif terhadap para penderita penyakit kronis, termasuk ESRD (AG Karger, 2008).

Menurut Smith (2010), memiliki sistem dukungan yang kuat dan tepat mampu mempercepat pemulihan dari episode depresi. Support system dari lingkungan terutama lingkungan keluarga sangat dibutuhkan oleh pasien. Dukungan keluarga merupakan suatu bentuk perhatian, dorongan yang didapatkan individu dari orang lain melalui hubungan 
interpersonal yang meliputi perhatian, emosional dan penilaian (Stolte, 2004, dalam Sunarti, 2009). Dampak positif dari dukungan keluarga adalah meningkatkan penyesuaian diri seseorang terhadap kejadian-kejadian dalam kehidupan. Sebab, dukungan yang tepat dapat membantu pasien dalam menghadapi stres, demikian sebaliknya dukungan yang tidak tepat dapat menimbulkan stress yang baru dan akan terakumulasi sehingga memperburuk keadaan (Arliza, 2006).

Jumlah pasien penderita penyakit gagal ginjal kronik di Indonesia diperkirakan 60.000 orang dengan pertambahan 4.400 pasien baru setiap tahunnya (Wijaya, 2009) dalam By_you (2010). Berdasarkan data yang peneliti dapatkan dari catatan registrasi di Unit Hemodialisa Rumah Sakit Gatoel Kabupaten Mojokerto mengalami peningkatan yaitu pada tahun 2012 terdapat 57 pasien GGK yang menjalani hemodialisa, tahun 2013 terdapat 112 pasien dan di tahun 2014 jumlah pasien yang menjalani hemodialisa naik menjadi 137 pasien. Hasil studi pendahuluan yang peneliti lakukan tanggal $1-20$ Juni 2015 dari 10 pasien yang menjalani Hemodialisa menunjukkan bahwa $20 \%$ pasien mengalami depresi ringan, $40 \%$ pasien mengalami depresi sedang, 20\% pasien mengalami depresi berat dan $20 \%$ pasien tidak mengalami depresi. Sedangkan bila dilihat dari ada tidaknya dukungan keluarga diperoleh hasil dengan rincian sebagai berikut, dari $20 \%$ pasien yang mengalami depresi ringan semuanya memperoleh dukungan keluarga baik, $40 \%$ pasien yang mengalami depresi sedang semuanya memperoleh dukungan keluarga cukup, dan dari $20 \%$ pasien yang mengalami depresi berat $10 \%$ nya memperoleh dukungan keluarga baik dan 10\% lagi memperoleh dukungan keluarga cukup, sedangkan $20 \%$ pasien yang tidak mengalami depresi semuanya memperoleh dukungan keluarga baik.

Menurut Roesli (2006) dalam Caninsti (2007) sistem dialisa bagi penderita GGK merupakan salah satu cara tindakan membantu kerja ginjal. Sedangkan pengobatan lain seperti transplantasi ginjal masih terbatas karena banyak kendala yang harus dihadapi, diantaranya ketersediaan donor ginjal, teknik operasi dan juga perawatan pada waktu pascaoperasi. Keadaan ketergantungan terhadap mesin dialisa mengakibatkan terjadinya perubahan dalam kehidupan penderita gagal ginjal terminal yang melakukan terapi hemodialisa. Perasaan kecewa dan putus asa terhadap hidupnya membuat pasien gagal ginjal kronik mengalami depresi. Perasaan kehilangan terhadap setiap aspek dari kehidupan normal yang pernah dimiliki akan terganggu. Oleh sebab itu, pasien memerlukan hubungan yang erat dengan seseorang yang bisa dijadikan tempat menumpahkan perasaannya pada saat stress dan kehilangan semangat (Smeltzer \& Bare, 2002).

Interaksi yang dekat, penghiburan, pertolongan dan perhatian yang diberikan seseorang disebut sebagai dukungan sosial. Dukungan sosial berfungsi untuk mengurangi stress karena melalui interaksi, seseorang dapat berpikir lebih realistis dan mendapatkan perspektif lain sehingga dapat lebih memahami masalahnya. Nasihat dan kasih sayang dari anggota keluarga dapat memberikan persepsi yang positif bagi individu untuk mencapai segala sesuatu dalam meraih impian yang dimilikinya, sehingga mereka yakin dan optimis terhadap harapan akan masa depannya. Selain itu diharapkan anggota keluarga yang sakit menjadikan keluarga sebagai kumpulan harapan, tempat bercerita, tempat bertanya, dan tempat mengeluarkan keluhan-keluhan bilamana individu sedang mengalami permasalahan. Dengan begitu penderita dapat meningkatkan kemampuan menghadapi stress dan mempercepat penyesuaian diri. Dari uraian diatas maka peneliti berminat untuk melakukan penelitian yang berjudul "Hubungan Dukungan Keluarga dengan Tingkat 
Depresi Pasien Gagal Ginjal Kronik yang Menjalani Hemodialisa di Rumah Sakit Gatoel Mojokerto".

Rumusan Masalah dalam penelitian ini adalah apakah ada hubungan dukungan keluarga dengan tingkat depresi pasien gagal ginjal kronik yang menjalani hemodialisa di Rumah Sakit Gatoel Mojokerto.

Tujuan umum penelitian ini adalah untuk mengetahui hubungan dukungan keluarga dengan tingkat depresi pasien gagal ginjal kronik yang menjalani hemodialisa di Rumah Sakit Gatoel Mojokerto.

Tujuan khusus penelitian ini adalah Mengidentifikasi dukungan keluarga, Mengidentifikasi tingkat depresi pasien gagal ginjal kronik dan menganalisis hubungan dukungan keluarga dengan tingkat depresi pasien gagal ginjal kronik yang menjalani hemodialisa di Rumah Sakit Gatoel Mojokerto.

Manfaat dalam penelitian ini adalah dapat menjadi masukan dan tambahan ilmu pengetahuan tentang depresi pada pasien yang menjalani terapi hemodialisa, sehingga perawat mempunyai kemampuan untuk menciptakan lingkungan yang terapeutik bagi pasien dengan tujuan mengembangkan koping adaptif melalui asuhan keperawatan yang diberikan.

\section{Metodelogi Penelitian}

Penelitian ini dilakukan mulai tanggal 23 Juli sampai 6 Agustus 2015 di Unit Hemodialisa Rumah Sakit Gatoel Mojokerto Desain penelitian yang dipakai dalam penelitian ini adalah Korelasi dengan pendekatan secara crosssectional, di mana peneliti melakukan pengukuran atau pengamatan pada saat bersamaan atau sekali waktu(Nursalam, 2003.hlm.28).

Populasi pada penelitian ini adalah semua pasien Gagal Ginjal Kronis yang menjalani terapi Hemodialisa di Rumah Sakit Gatoel Mojokerto sebanyak 30 orang.
Pengambilan sampel dalam penelitian ini menggunakan teknik nonprobability sampling, yaitu consecutive sampling. Menurut Sastroasmoro\& Ismail (1995) dalam Nursalam (2008) yang dimaksud consecutive sampling adalah pemilihan sampel dengan menetapkan subyek yang memenuhi kriteria penelitian, dimasukkan dalam penelitian sampai kurun waktu tertentu, sehingga jumlah responden yang diperlukan terpenuhi.

Pada penelitian ini yang menjadi variabel independen adalah dukungan keluarga dan Variabel Dependen dalam penelitian ini adalah tingkat depresi.

Teknik pengumpulan data pada penelitian ini adalah mengukur tingkat depresi terlebih dahulu dan kemudian mengukur dukungan keluarga. Semua variabel diukur dengan menggunakan kuesioner tertutup, kuesioner diisi dengan memberikan ceklist $(\sqrt{ })$ pada poin yang sesuai. Peneliti melakukan proses pengumpulan data yaitu sebagai berikut :membacakan kuesionerdan responden menentukan sendiri pada salah satu pilihan item dari pernyataan yang sesuai, cara ini dipergunakan untuk mengukur tingkat depresi dan dukungan keluarga. Selanjutnya data-data tersebut dikumpulkan oleh peneliti untuk dilakukan pengolahan serta analisis data.

Peneliti memasukkan data yang telah dikumpulkan kedalam master tabel atau data base komputer, kemudian membuat distribusi frekuensi sederhana atau dengan membuat tabel kontingensi.Setelah data diolah kemudian dianalisa, sehingga hasil analisa data dapat dipergunakan sebagai bahan pengambilan keputusan penanggulangan masalah (Setiadi, 2007).

\section{Hasil Penelitian \\ 1. Hasil}

Hubungan dukungan keluarga dengan tingkat depresi pasien gagal ginjal kronis yang menjalani hemodialisa. 


\begin{tabular}{|c|c|c|c|c|c|c|c|c|c|c|c|}
\hline \multirow{3}{*}{ Variabel } & \multicolumn{9}{|c|}{ Tingkat Depresi } & \multirow{2}{*}{\multicolumn{2}{|c|}{ Jumlah }} \\
\hline & \multicolumn{3}{|c|}{$\begin{array}{c}\text { Tidak } \\
\text { Depresi }\end{array}$} & \multicolumn{2}{|c|}{ Ringan } & \multicolumn{2}{|c|}{ Sedang } & \multicolumn{2}{|c|}{ Berat } & & \\
\hline & $\sum$ & & $\%$ & $\sum$ & $\%$ & $\sum$ & $\%$ & $\sum$ & $\%$ & $\sum$ & $\%$ \\
\hline \multirow{3}{*}{$\begin{array}{c}\text { Dukungan } \\
\text { Keluarga }\end{array}$} & Kurang & - & - & - & - & - & - & - & - & - & - \\
\hline & Cukup & - & - & 5 & 17 & 9 & 30 & 2 & 7 & 16 & 53 \\
\hline & Baik & 3 & 10 & 7 & 23 & 3 & 10 & 1 & 3 & 14 & 47 \\
\hline Jumlah & 3 & & 10 & 12 & 40 & 12 & 40 & 3 & 10 & 30 & 100 \\
\hline
\end{tabular}

Data hasil uji statistik yang peneliti lakukan untuk mengetahui hubungan dukungan keluarga dengan tingkat depresi pasien gagal ginjal kronis yang menjalani hemodialisa yang dianalisa menggunakan bantuan perangkat lunak SPSS dengan uji Rank Spearman Test diperoleh nilai $\mathrm{p}$ $=0,020<\alpha=0,05$. Dengan demikian H1 diterima yang artinya ada hubungan dukungan keluarga dengan tingkat depresi pasien gagal ginjal kronis yang menjalani hemodialisa di Rumah Sakit Gatoel Mojokerto.

\section{Pembahasan}

Dari hasil penelitian ini telah mengambarkan bahwa sebagian besar atau 16 responden (53\%) telah memperoleh dukungan keluarga dengan cukup. Responden dan keluarga cukup memahami akan pentingnya dukungan, perawatan kesehatan, keluarga mampu menciptakan kondisi yang nyaman, memberian motivasi dan menerima keadaan responden yang mengalami masalah kesehatan kronis.

Dari tabel diatas juga dijelaskan bahwa 14 responden (47\%) memperoleh dukungan keluarga baik. Hal ini mungkin dipengaruhi oleh kurangnya frekuensi dampingan keluarga saat menjalani hemodialisa akibat kesibukan dari masingmasing anggota keluarga dalam bekerja mengingat sebagian besar keluarga memiliki pekerjaan swasta.
Dengan demikian diharapkan pada setiap anggota keluarga untuk memahami akan pentingnya kebersamaan dan meningkatkan dukungannya pada anggota keluarga lain yang sedang mengalami permasalahan baik fisik maupun psikologis sebab keluarga merupakan lingkungan sosial yang utama dalam hal kedekatan sosialisasi baik intensitas maupun frekuensi. Setidaknya menjaga hubungan yang harmonis, penghargaan, dan kedekatan emosi sehingga kebutuhan masing-masing individu dalam keluarga terpenuhi tanpa mengabaikan hak dan kewajiban anggota keluarga lainnya. Yang pada akhirnya keluarga dapat memenuhi tugas dalam menjalankan fungsinya sebagai pemberi perawatan kepada anggota keluarga yang sedang sakit.

\section{Tingkat depresi}

Dari hasil penelitian dapat dipertegas bahwa mayoritas pasien yang rutin menjalani hemodialisa mengalami depresi yaitu 27 responden (90\%) yang terbagi atas 3 tingkatan depresi. Namun pada kenyataan yang terjadi di lapangan, dari 30 responden $(100 \%)$ proporsi jumlah responden yang mengalami depresi ringan merupakan yang paling tinggi. Hal ini dapat dikaitkan bahwa mayoritas responden telah lama menjalani hemodialisa sehingga secara tidak langsung telah mengalami fase adaptasi. 
Hubungan dukungan keluarga dengan tingkat depresi pasien gagal ginjal kronis yang menjalani hemodialisa di Rumah Sakit Gatoel Mojokerto

Hasil analisa melalui bantuan perangkat lunak SPSS dengan ujiRank Spearman Test yang dilakukan pada tanggal 6 Agustus 2015 didapatkan hasil $p$ $=0,020$ dengan tingkat signifikasi $\alpha=$ 0,05 , maka $\mathrm{H} 1$ diterima yang artinya ada hubungan dukungan keluarga dengan tingkat depresi pasien gagal ginjal kronis yang menjalani hemodialisa di RS Gatoel Mojokerto.Dari 30 responden 12 responden $(40 \%)$ yang mengalami depresi ringan semuanya memperoleh dukungan keluarga baik, 12 responden (40\%) pasien yang mengalami depresi sedang semuanya memperoleh dukungan keluarga cukup, 3responden (10\%) yang mengalami depresi berat semuanya memperoleh dukungan keluarga cukup sedangkan 3 responden(10\%) yang tidak mengalami depresi semuanya memperoleh dukungan keluarga baik.

\section{KESIMPULAN}

Berdasarkan hasil penelitian yang telah dilakukan maka dapat dirumuskan suatu kesimpulan sebagai berikut :

1. Pasien yang menjalani hemodialisa di RS Gatoel sebanyak 16 responden memperoleh dukungan cukup

2. Pasien yang menjalani hemodialisa di Rumah Sakit Gatoel Hampir separuh responden mengalami depresi ringan dan sedang.

Ada hubungan dukungan keluarga dengan tingkat depresi pasien gagal ginjal kronis yang menjalani hemodialisa di Rumah Sakit Gatoel Mojokerto.

\section{DAFTAR PUSTAKA}

AG, Karger. 2008. Nephron Clinical Practice "Depresi pada Dialisis", Vol. 108, No. 4, (http:// karger. com/ Nec), diakses 10 Desember 2010
Akhmadi. 2007. Pendidikan Umum, (http://rajawana. com), diakses 21 desember 2010

Anon. 2011. Diagnosa Depresi, (http://WebMD. com), diakses 13 Januari 2011

Anon. 2011. Penyakit Ginjal Kronis, (http:// wikipedia.com), diakses 13 Januari 2011

Anon. 2008. Stress pada pasien Hemodialisa, (http:// zonapsikologi.com), diakses 14 Desember 2010

Arliza, JL. 2006. "Dukungan Sosial pada Pasien Gagal Ginjal Terminal yang Melakukan Terapi Hemodialisa". Skripsi program studi Psikologi tidak dipublikasikan. Universitas Sumatra Utara

By_you. 2010. Gagal Ginjal Kronis, (http://by_you. com), diakses 11 Desember 2010

Caninsti, Risselligia. 2007. "Gambaran Kecemasan dan Depresi pasien Gagal Ginjal Terminal yang Melakukan Terapi Hemodialisa". Skripsi Psikologi tidak dipublikasikan. Universitas Sumatra Utara

Davison, Gerald C. (2006). Psikologi Abnormal Edisi 9. Jakarta : EGC

Franklin, Donald J., Ph. D. 2003. Pscychology Information Online, (http://IPO.com), diakses 13 Januari 2011

Fredric \& Susan. 2010. Asosiasi Eropa dialisis dan Asosiasi Transplantasi. "Depresi pada pasien dialisis kronis", 
(http://oxfordjurnal.com), diakses 10 Desember 2010

Freedman, Marlin E. 2010. Konsep, Teori dan Praktek Keperawatan Keluarga. Jakarta : EGC

Guyton, Arthur C \& Jhin E. Hall. 2008. Buku Ajar Fisiologi Kedokteran Edisi 11. Jakarta : EGC

Hidayat, Aziz Alimul. 2008. Metode Penelitian Keperawatan dan Teknik Analisis Data. Jakarta : Salemba Medika

Mansjoer, Arif., Kuspuji Trianti., Rakhmi Savitri., Wahyu Ika Wardhani., Wiwiek Setiowulan. 2009. Kapita Selekta Kedokteran Edisi 3. Jakarta : Media Aeskulapius

Marlin, Lucian E. 2008. Referensi Kesehatan, (http://worldpress. com), diakses 14 Maret 2011

Mayo Clinic. 2010. Mayo Foundation untuk Pendidikan dan Penelitian Medis "Dukungan kelompok untuk Depresi", (http://mayoclinic.org), diakses 13 Januari 2011

Nursalam. 2008. Konsep dan Penerapan Metodologi Penelitian Ilmu Keperawatan, Pedoman Skripsi, Tesis, dan Instrumen Penelitian Keperawatan. Jakarta : Salemba Medika

OMNI Medical. 2010. Mental Kesehatan Psikologis, (http://omnimedicalsearch. org), diakses 13 Januari 2011

Peraturan Pemerintah (PP) nomor 21. $1994 . \quad$ Penyelenggaraan Pembangunan Keluarga Sejahtera
Price, Sylvia A \& Lorraine M. Wilson. 2006. PATOFISIOLOGI Konsep Klinis Proses-Proses Penyakit Edisi 6. Jakarta: EGC

Setiadi. 2007. Konsep dan Penulisan Riset Keperawatan. Yogyakarta : Graha Ilmu

Simon, Gregory E. 2001. Western Journal of Medicine, (http:// wjm. com), diakses 14 Maret 2011

Silalahi, Gabriel A. 2003. Metodologi penelitian dan Studi Kasus. Sidoarjo: Citraa Medika

Smeltzer, Suzanne C \& Brenda G. Bare. 2002. Buku Ajar Keperawatan Medikal Bedah Edisi 8. Jakarta : EGC

Smith, Melinda, dkk. 2010. Expert, Adfree Resource Help You Resolve health challenges, (http://helpguide.org), diakses 3 Januari 2011

Sunarti. 2009. "Hubungan Antara Dukungan Keluarga dengan Kepatuhan Menjalani Hemodialisa pada Penderita Gagal Ginjal Kronis di RSUD dr. Moewardi Surakarta". Skripsi Sarjana keperawatan tidak dipublikasikan. FIK UNMUH Surakarta

Supriyatno, Endro., Sp. KJ. 2009. Depresi dan Penanganannya, (http://psikofarmaka_psikiatri.co m), diakses 13 Januari 2011 